\title{
KAJIAN PENGEMBANGAN TAMBAK GARAM DI PULAU TANAKEKE KABUPATEN TAKALAR
}

\author{
(Study for Development of Salt Pond in Tanakeke Island of Takalar Regency) \\ Jusran $^{1)}$, Muhammad Kasnir ${ }^{2)}$ dan Abdul Rauf ${ }^{2)}$ \\ 1) Mahasiswa PascaSarjana Universitas Muslim Indonesia \\ ${ }^{2)}$ Dosen Program Studi Manajemen Pesisir dan Teknologi Kelautan, \\ Pascasarjana Universitas Muslim Indonesia
}

Korespondensi:jusran_bakorluh@yahoo.co.id

Diterima: tanggal 15 Juli 2020; Disetujui 20 September 2020

\begin{abstract}
Salt is one of the national strategic commodities. But until now the notional needs of salt have not been met by national salt production in the country, one of the efforts to increase salt production in the country is to optimize existing potential salt field. The island of tanakeke in takalar district of southern sulawesi province has a potential salt field, wich is not yet well watered. The reseach's aims (1) to anayize potential land appropriations for the development of salt pans on tanakeke island (2) to analize the salt-farm development cost (3) to determine salt pond development strategies based on the characteristics of the research area. Research suggetts that the total potential land most suitable for development of salt pond at 1.106,58 ha or about 38,91\% of the total land on Tanakeke islands. Based on the financial analysis of the salt pond with geomembran method on an acre of land on tanakeke islands are feasible to continue. Followed by the investment criteria acquired by $N P V>1, N e t B / C>1$ and IRR $>$ discount rate. Selected combination of strategies (1) Priority strategies; Training in increased human resource capacity and Infrastructure improvements. (2) altenative strategies; salt regulatory improvements.
\end{abstract}

Keywords: $\quad$ Salt Pond, land compatibility, financial analysis, development strategies

\begin{abstract}
ABSTRAK
Garam merupakan salah satu komoditas strategis nasional. Namun hingga saat ini kebutuhan garam nasional belum dapat terpenuhi oleh produksi garam dalam negeri. Salah satu upaya dalam meningkatkan produksi garam dalam negeri adalah mengoptimalkan potensi lahan garam yang ada. Pulau Tanakeke yang terletak di Kabupaten Takalar Provinsi Sulawesi Selatan memiliki potensi lahan garam yang belum tergarap dengan baik. Tujuan penelitian ini adalah (1) Menganalisis luas kesesuaian lahan potensial untuk pengembangan tambak garam di Pulau Tanakeke (2) Menganalisis tingkat kelayakan usaha pengembangan tambak garam (3) Menentukan strategi pengembangan tambak garam berdasarkan karateristik wilayah penelitian. Hasil penelitian menujukkkan bahwa total lahan potensial yang paling sesuai untuk pengembangan tambak garam sebesar 1.106,58 ha atau sekitar 38,91\% dari total lahan yang ada di Pulau Tanakeke. Berdasarkan hasil analisis kelayakan finansial tambak garam dengan metode geomembran pada lahan seluas satu hektar di Pulau Tanakeke layak untuk dilanjutkan dengan kriteria investasi yang di peroleh bahwa NPV $>1$, Net B/C $>1$ dan IRR $>$ discount rate. Kombinasi strategi yang dipilih (1)Strategi Prioritas : Pelatihan-pelatihan peningkatan kapasitas sumber daya manusia dan Perbaikan infrastruktur (2)Strategi Alternatif : Perbaikan regulasi tata niaga garam.
\end{abstract}

Kata kunci : $\quad$ tambak garam, kesesuaian lahan, analisis finansial, strategi pengembangan 


\section{PENDAHULUAN}

Garam menjadi salah satu komoditas perdagangan cukup penting, karena dalam beberapa tahun terakhir ini menjadi isu strategis nasional yang sangat menarik banyak pihak baik pemerintah, pers, pelaku bisnis maupun akademisi. Hal itu antara lain terkait dengan rendahnya produktivitas garam nasional yang menyebabkan Indonesia harus mengimpor garam dari beberapa negara untuk memenuhi kebutuhan dalam negerinya(Rochwulaningsih, 2013).

Salah satu sentra produksi garam nasional, Pemerintah Provinsi Sulawesi Selatan terus berupaya dalam berkontribusi terhadap peningkatan produksi garam setiap tahunnya.Upaya tersebut dilakukan melalui optimalisasi produksi tambak garam yang telah ada serta melakukan inventarisasi lahanlahan potensial untuk pengembangan tambak garam (Antara News, 2017)

Kabupaten Takalar merupakan salah satu daerah penghasil garam di Provinsi Sulawesi Selatan, dimana daerah ini cukup strategis bagi pengembangan komoditas garam karena memiliki potensi sumberdaya alam pesisir dan laut yang melimpah dengan panjang garis pantai sekitar
95,8 $\mathrm{km}$ yang terbentang di sepanjang pesisir Pantai Barat Selat Makassar sampai dengan pesisir Pantai Selatan Laut Flores (DKP Prov. Sulsel, 2017).

Dalam dua tahun terakhir pengusahaan garam di Kabupaten Takalar khususnya di Pulau Tanakeke dimana telah dilakukanuji coba pengembangan komoditas garam dengan pembuatan ladang-ladang garam pada musim kemarau, sedangkan pada musim penghujan dimanfaatkan untuk budidaya ikan.Petambak garam Pulau Tanakeke sudah mampu menghasilkan garam dari ladang-ladang yang dibuat.(DKP Prov. Sulsel, 2017).

Hasil observasi awal di tahun 2018 yang dilakukan diketahui bahwa potensi luasan tambak di Pulau Tanakeke adalah 2.144,95 ha sedangkan untuk di 3 desa yang menjadi lokasi penelitian potensi tambak eksisting yang ada, antara lain Desa Tompotana seluas 7.16,43 ha, Desa Maccinibaji seluas 271,44 ha dan Desa Balangdatu seluas 1.026,46 ha.(DKP Prov. Sulsel, 2018).

Berdasarkan hal tersebut di atas maka dipandang perlu untuk melakukan suatu kajian terkait pengembangan tambak garam di Pulau 
Tanakeke.Hasil kajian ini diharapkan dapat dijadikan sebagai bahan informasi bagi pemerintah setempat dalam rangka merumuskan kebijakan pengembangan komoditas garam sebagai salah satu alternatif bagi peningkatan pendapatan masyarakat pesisir khususnya petambak garam.Selain itu, juga diharapkan dapat berkontribusi bagi pendapatan daerah sekaligus mendukung upaya November2019.

\section{METODE PENELITIAN}

\section{Lokasi dan WaktuPenelitian}

Penelitian ini dilaksanakan di Pulau Tanakeke yang meliputi 3 (tiga) desa yakni Desa Tompotana, Maccinibaji dan Balangdatu Kecamatan Kepulauan Tanakeke Kabupaten Takalar Provinsi Sulawesi Selatan.Pengambilan data dilaksanakan pada bulan Oktober sampai dengan

pemenuhan kebutuhan garam nasional.

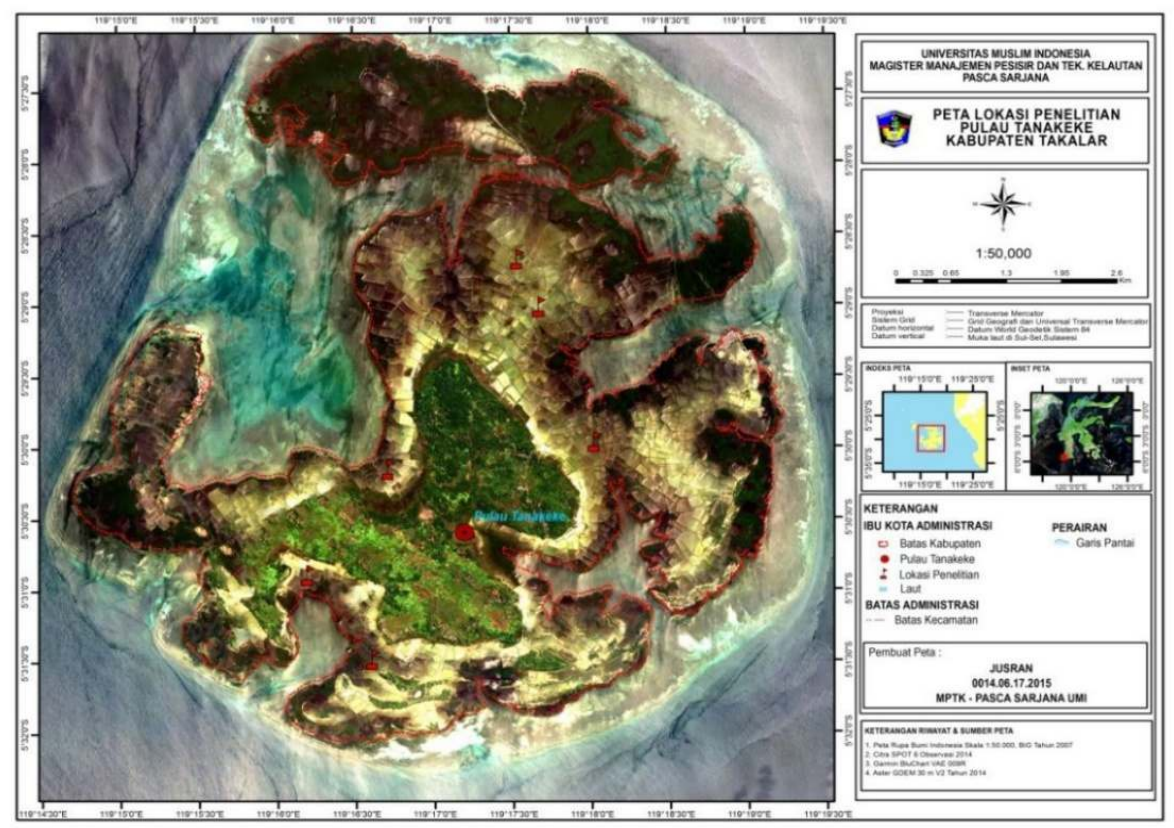

Gambar 1. Peta lokasi penelitian

\section{Alat dan Bahan}

Alat-alat yang digunakan dalam penelitian ini adalah alat untuk mengukur aspek-aspek yang terkait dengan parameter yang menjadi indikator dalam melakukan analisis dalam penelitian, antara lain; GPS
(Global Position System) untuk penentuan posisi saat penilitian, Kamera Digital untuk keperluan dokumentasi, Alat tulis menulis dan Formulir Kuesioner untuk pengambilan data sosial masyarakat petambak garam serta bahan pustaka yang berkaitan 
dengan penelitian ini. Sedangkan, penulis menggunakan teknik bahan yang digunakan dalam penelitian pengumpulan data sebagai berikut:

adalah bahan yang digunakan untuk pengolahan data citra dan pengambilan substrat sebelum diidentifikasi di Laboratorium (Citra Spot 6 Akusisi 2018, Peta RBI Bakosurtanal 2010 dan Kantong sampel).

\section{Jenis dan Sumber Data}

Jenis data yang digunakan dalam penelitian ini adalah data primer dan data sekunder.Data primer berupa data langsung dari responden yang ditentukan berdasarkan keterwakilannya, diperoleh melalui metode wawancara dan kuesioner.

1. Studi Kepustakaan yaitu mengumpulkan data yang diperoleh dari mempelajari dan menelaah sumber rujukan yaitu buku, makalah, jurnal ilmiah, surat kabar, atau bentuk-bentuk tulisan lainnya yang berkaitan dengan topik penelitian.

2. Studi Lapangan yaitu peneliti mengumpulkan data dengan cara turun langsung ke lokasi penelitian untuk memperoleh data dan fakta yang berkaitan dengan masalah yang diteliti.

Data sekunder diperoleh dari instansi terkait antara lain data desa, dinas kelautan dan perikanan, bappeda dan instansi lainnya. Data tersebut dapat berupa bahan pustaka, dokumendokumen, laporan hasil penelitian dan tulisan ilmiah yang menunjang penelitian ini.

\section{Teknik Pengumpulan Data}

Untuk memperoleh data yang diperlukan dalam penelitian ini maka

\section{Analisis Data}

\section{Analisis Spasial Kesesuaian Lahan Tambak Garam}

Metode SIG yang dipergunakan dalam penelitian ini adalah pemodelan spasial.Pemodelan spasial dilakukan untuk kajian pemilihan lokasi (site selection) yang sesuai untuk tambak garam.Pemodelan SIG tersebut dapat memprediksi tambak yang sesuai, kurang sesuai dan tidak sesuai untuk tambak garam. 
Tabel 1. Kriteria kesesuaian lahan untuk tambak garam

\begin{tabular}{ccccc}
\hline Parameter & \multicolumn{4}{c}{ Kelas Kesesuaian Lahan } \\
\cline { 2 - 5 } & $\mathrm{S} 1$ & $\mathrm{~S} 2$ & $\mathrm{~S} 3$ & $\mathrm{~N}$ \\
\hline Kelerengan (\%) & $0-2$ & $>2-3$ & $>3-4$ & $>4$ \\
Tekstur Tanah (S) & $\begin{array}{c}\text { lempung liat } \\
\text { berpasir } \\
\text { (sandy clay } \\
\text { loam) }\end{array}$ & $\begin{array}{c}\text { liat berpasir } \\
\text { (sandy clay) }\end{array}$ & $\begin{array}{c}\text { liat berdebu } \\
\text { (silty clay) }\end{array}$ & $\begin{array}{c}\text { debu,pasir } \\
\text { (silt,sand) }\end{array}$ \\
Curah Hujan & $<1300$ & $>1300-1350$ & $>1350-$ & $>1400$ \\
(mm/thn) & & & 1400 & \\
Jarak dari Garis & $>100-1000$ & $>100-2000$ & $>2000-$ & $0-100,>4000$ \\
Pantai (m) & & & 4000 & $>2000$ \\
Jarak dari Sungai (m) & $0-500$ & $>500-1000$ & $>1000-$ & 2000 \\
Tutupan Lahan & tambak garam, & sawah,kebun & $\begin{array}{c}\text { rawa,tamba } \\
\text { k budidaya }\end{array}$ & $\begin{array}{c}\text { Pemukiman } \\
\text { hutan } \\
\text { mangrove } \\
\text { tegalan, belukar }\end{array}$ \\
Ketinggian Air (Cm) & 5-10 & $10-15$ & 15-20 & $>20$ \\
\hline Sumber: Pantjara et al. (2008), Muhsoni.F. (2012) & & &
\end{tabular}

\section{Analisis Kelayakan Usaha}

\section{Pengembangan Tambak Garam}

Analisis kelayakan usaha menggunakan beberapa kriteria investasi yang didasarkan pada perhitungan nilai sekarang (present value) arus benefit dan arus biaya selama umur proyek. Kriteriakriteria tersebut terdiri atas:

\section{Net Present Value (NPV)}

Net Present Value adalah nilai kini dari keuntungan bersih yang akan diperoleh pada masa mendatang dan merupakan selisih antara present value dari benefit dan present value dari biaya. Rumus NPV menurut Kadariah, L Karlina, C. Gray (1978) adalah:

$$
N P V=\sum_{t=0}^{n} B t-C t
$$

Dengan kriteria usaha, bila nilai (NPV > 0), maka usaha tersebut dinyatakan layak untuk dilaksanakan. Jika $(\mathrm{NPV}=0)$, berarti usaha tersebut mengembalikan sama besarnya dengan nilai uang yang ditanamkan untuk mencapai hasilnya, sedangkan bila $(\mathrm{NPV}<0)$, usaha ini tidak layak untuk dilaksanakan.

\section{Net Benefit-Cost Ratio (Net B/C)}

Net Benefit-Cost Ratio adalah perbandingan antara present value total dari benefit bersih pada tahun-tahun dimana benefit bersih bernilai positif, dengan present value total dari benefit bersih pada tahun tahun dimana $\mathrm{Bt}-\mathrm{Ct}$ bernilai 
negatif, yaitu biaya kotor lebih besar dari benefit kotor. Rumus Net BEC menurut Kadariah, Karlina, dan Gray., (1978) adalah :

$$
\begin{aligned}
& \frac{N e t B}{C} \\
& =\frac{\sum_{t=0}^{n} \frac{(B t-C t)}{(1+i) t} ; \operatorname{untuk}(B t-C t \geq 0)}{\sum_{t=0}^{n} \frac{(B t-C t)}{(1+i) t} ; \operatorname{untuk}(B t-C t \leq 0)}
\end{aligned}
$$

Kriteria keputusan yang

diambil dalam analisis ini adalah layak atau menguntungkan, jika nilai (Net B/C $\geq 1)$, tetapi jika (Net B/C $<1$ maka usahanya rugi atau dinyatakan tidak layak untuk dilaksanakan

3. Internal Rate of Return (IRR)

\section{AnalisisStrategipengembangan} Tambak Garam.

Analisis SWOT digunakan sebagai upaya untuk menentukan alternatif strategi yang dianggap sesuai untuk pengembangan tambak garam Pulau Tanakeke.

Penentuan faktor-faktor dari setiap komponen SWOT dan pembobotannya diperoleh dari hasil wawancara dengan responden.Wawancara adalah
IRR adalah tingkat suku bunga yang menunjukkan jumlah nilai sekarang netto (NPV) sama dengan jumlah seluruh ongkos investasi proyek atau NPV $=0$. Dengan kata lain, IRR adalah suatu tingkat bunga dimana seluruh net cash flow sesudah di present value sama jumlahnya dengan biaya investasi. Nilai IRR yang lebih besar atau sama dengan Bunga Bank yang berlaku, Rumus Perhitungan IRR menurut Kadarsan, (1995) adalah sebagai berikut :

$$
I R R=i_{1}+\frac{N P V_{1}}{N P V_{1}+N P V_{2}} x\left(i_{2}-i_{1}\right.
$$

komunikasi langsung antara peneliti dan informan.

\section{HASIL DAN PEMBAHASAN}

\section{Kondisi Fisik Lokasi Penelitian}

a.Kelerengan

$$
\text { Pulau Tanakeke }
$$

merupakan daratan yang memiliki kondisi topografi cenderung datar hingga landai.Hasil analisis yang dilakukandiketahui bahwa Tanakeke berada pada ketinggian antara $0-33 \mathrm{~m}$. 


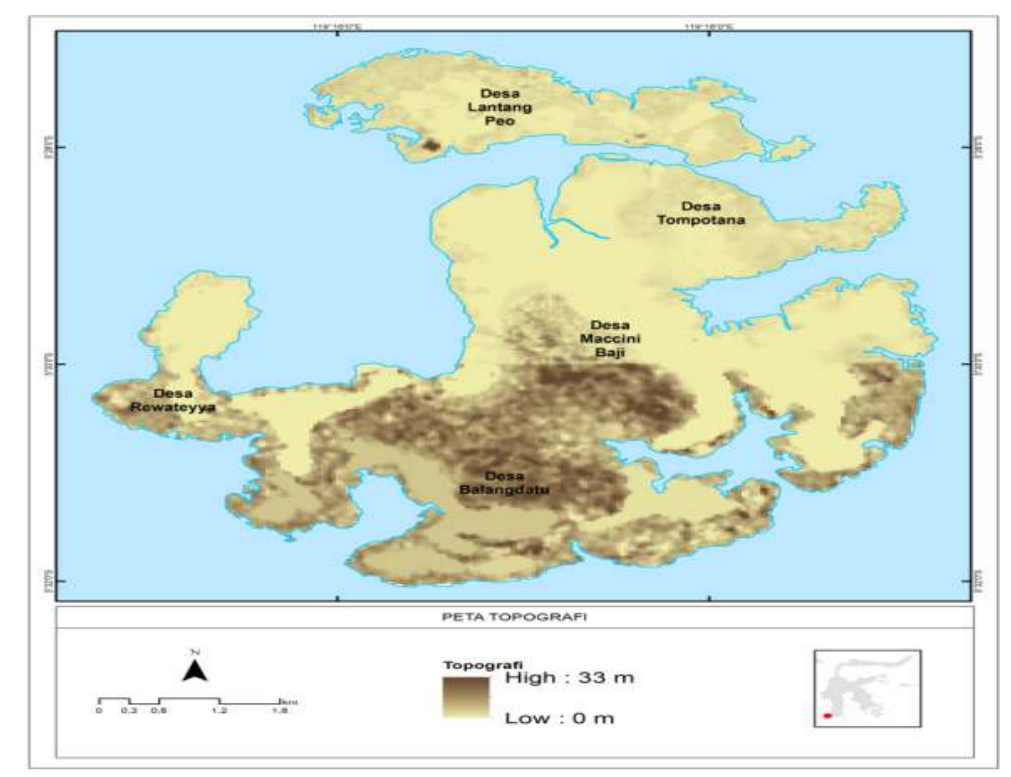

Gambar 2.Peta topografi Pulau Tanakeke

Selanjutnya data kondisi diketahui terdiri dari berbagai jenis topografis tersebut digunakan untuk kelerengan, yaitu 0 sampai $>4 \%$ mengukur tingkat kelerengan Pulau dengan rincian dapat dilihat pada Tanakeke.Wilayah Pulau Tanakeke gambar 8 berikut.

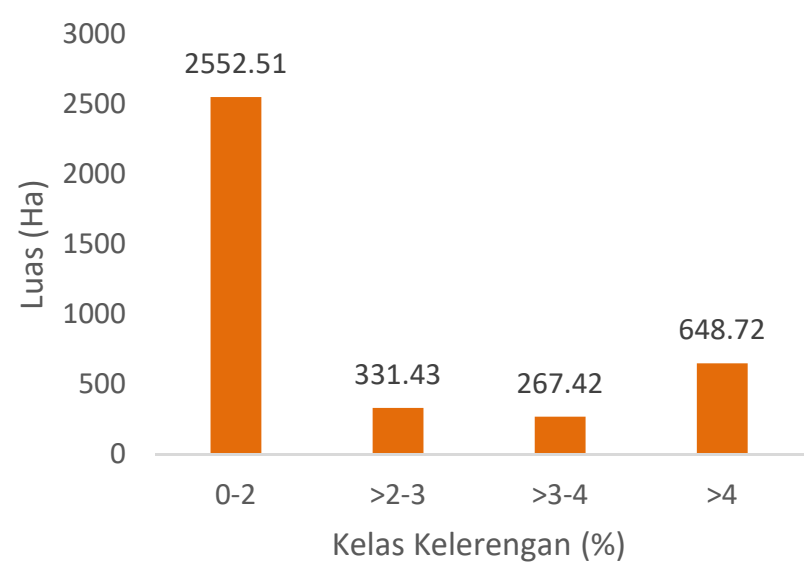

Gambar 3. Grafik kelerengan Pulau Tanakeke

b. Tekstur Tanah

Berdasarkan hasil analisis adalah lempung berliat dan liat sampel tanah yang di lakukan berdebu.

diketahui bahwa untuk tekstur tanah pada lokasi penelitian umumnya 


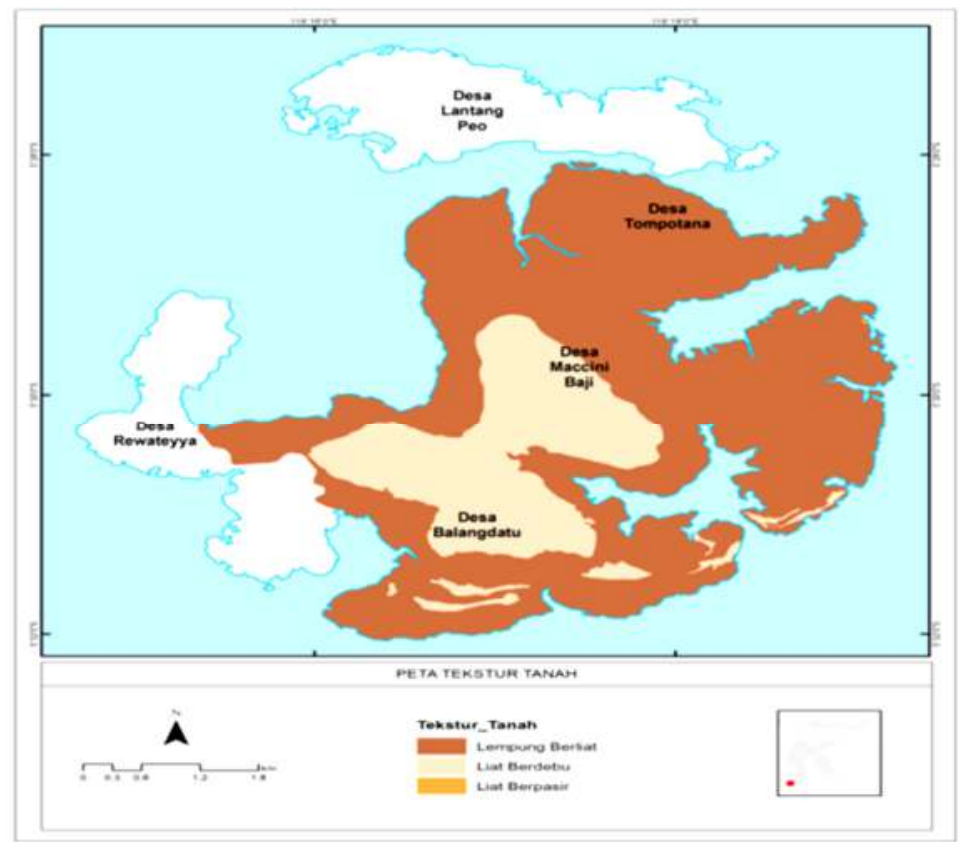

Gambar 4. Peta tekstur tanah Pulau Tanakeke

c. Curah Hujan

Menurut data BPS (2019) Jumlah hari hujan terbanyak berada di dikatakan bahwa Kabupaten Takalar bulan Januari, yaitu sebanyak 22 yang meliputi Pulau Tanakeke hari.Meski begitu, curah hujan yang memiliki jumlah hari hujan dalam paling tinggi terjadi di bulan Desember setahun sekitar 142 hari dengan curah dengan intensitas sebesar $707 \mathrm{~mm}^{3}$.

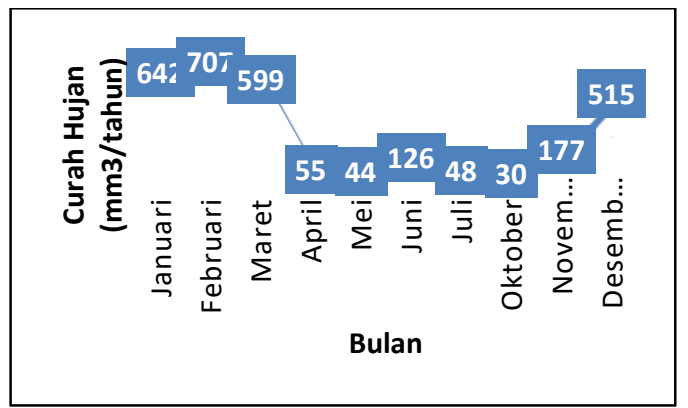

Gambar 5. Grafik curah hujan tiap bulan Kabupaten Takalar 


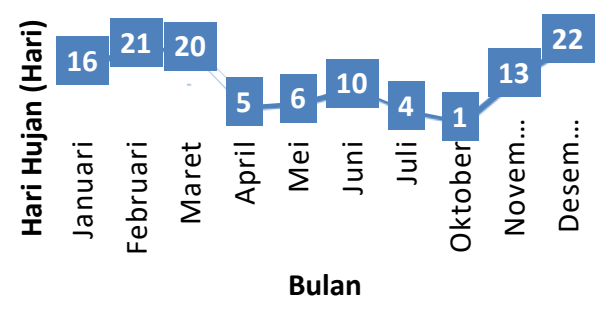

Gambar 6. Grafik jumlah hari hujan tiap bulan Kabupaten Takalar

Dari grafik di atas dapat pada jarak 0-1000 meter. Kondisi ini diketahui bahwa wilayah Takalar tentunya mendukung dalam khususnya Pulau Tanakeke memiliki pengembangan tambak garam.Semakin curah hujan yang mendukung dalam dekat jarak garis pantai maka semakin pengembangan tambak garam. baik untuk pengusahaan garam namun

d. Jarak Dari Garis Pantai perlu juga untuk mempertimbangkan

Kondisi Pulau Tanakeke Kawasan-kawasan konservasi yang berdasarkan jarak dari garis pantai telah ditetapkan sesuai dengan regulasi diketahui bahwa pada umumnya berada yang ada.

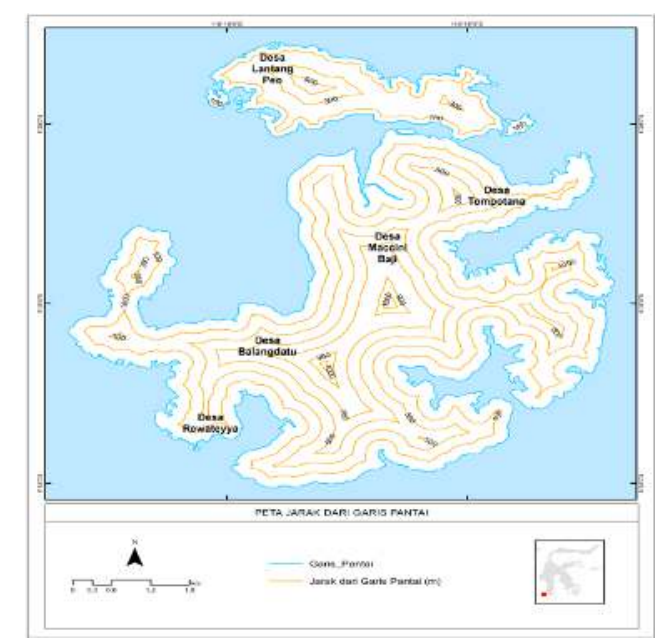

Gambar 7. Peta jarak dari garis pantai Pulau Tanakeke

e. Jarak Dari Sungai

Untuk Pulau Tanakeke, kondisi hidrologi bukan merupakan sungai tapi jalur/saluran air laut baik itu merupakan buatan maupun yang alami terbentuk. Saluran-saluran air buatan merupakan saluran untuk pengairan tambak eksisting yang ada dan juga dimanfaatkan oleh masyarakat setempat untuk sarana atau alur transportasi kapal. 


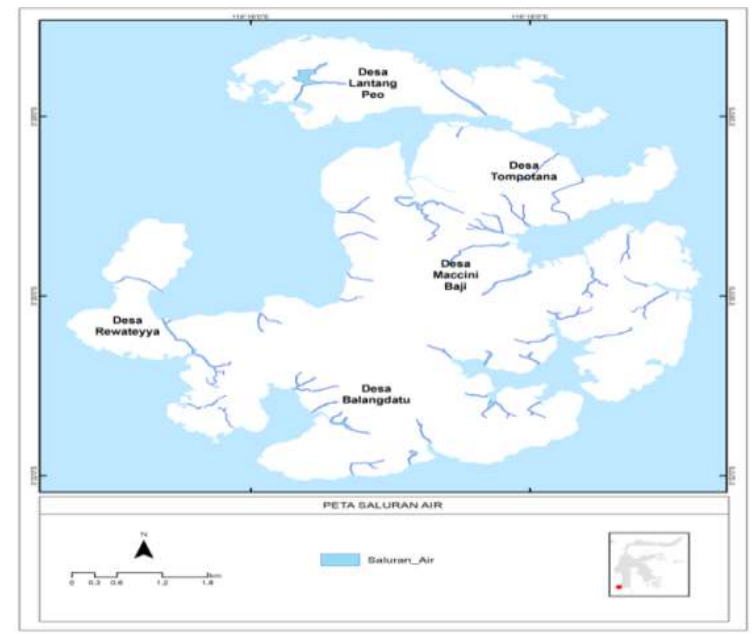

Gambar 8. Sebaran saluran air Pulau Tanakeke

Dari hasil observasi lapangan diketahui bahwa untuk tutupan lahan dan interpretasi citra satelit yang pada Pulau Tanakeke terdiri atas dilakukan diketahui sebagian besar kebun, mangrove, pemukiman, saluran saluran-saluran ini lokasinya air, semak/belukar, tambak, dan berdekatan dengan lahan-lahan tambak vegetasi. Tutupan lahan di dominasi yang ada dan berjarak antara 0 sampai oleh tambak dengan luas sebesar $1,5 \mathrm{~km}$ ke arah daratan.

f. Tutupan Lahan wilayah pulau Tanakeke.

Hasil interpretasi citra satelit yang dilakukan

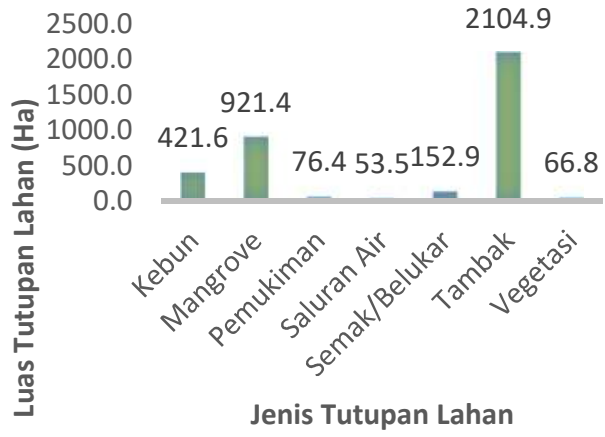

Gambar 9. Grafik luasan tutupan lahan Pulau Tanakeke 


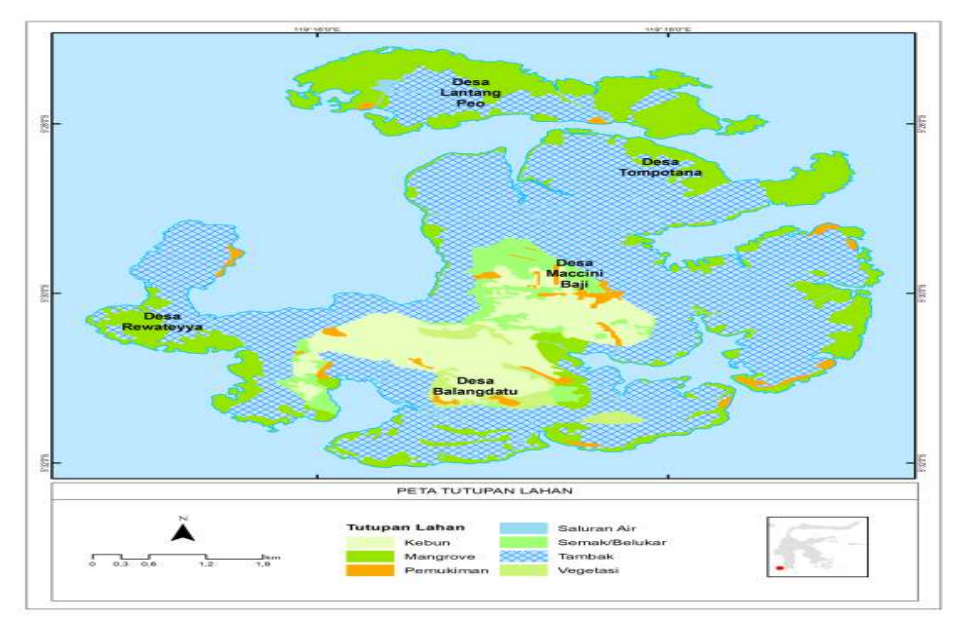

Gambar 10. Petatutupan lahan Pulau Tanakeke

g. Ketinggian Air

Untuk kondisi pasang surut

Pulau Tanakeke merujuk pada penelitian sebelumnya di lokasi penelitian. Hasil kajian Rahman et al. (2017) menyebutkan bahwa kondisi pasang surut Kabupaten Takalar memiliki bilangan
Formzhal 1.7 sehingga dapat disimpulkan bahwa tipe pasang surut daerah penelitian adalah pasang surut campuran condong keharian tunggal dengan pasang tertinggi $0.58 \mathrm{~m}$ dan nilai surut terendah $-0.77 \mathrm{~m}$.

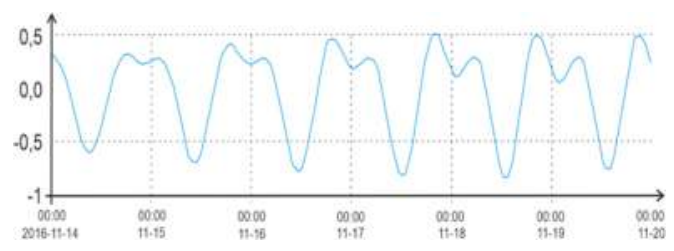

Gambar 11.Grafik pasang surut Kabupaten Takalar (Pulau Tanakeke)

\section{Analisis KesesuaianLahan Tambak}

\section{Garam}

Dari hasil analisis kesesuaian lahan tambak garam yang dilakukan dengan menggunakan teknologi sistem informasi geografis (SIG) diketahui bahwa luas lahan paling layak untuk pengembangan tambak garam adalah $1.106,58$ dari total luas lahan potensial yang sesuai untuk pengembangan tambak garam di Pulau Tanakeke Kabupaten Takalar yang luasnya \pm 2.387,81 ha.. Sebagaimana tertera pada tabel dan gambar berikut ini. 
Tabel 2.Luas lahan paling layak dalam pengembangan tambak garam Pulau Tanakeke.

\begin{tabular}{|c|c|c|}
\hline No & Desa & $\begin{array}{l}\text { Luas } \\
\text { (Ha) }\end{array}$ \\
\hline 1 & Desa Tompotana & 487,35 \\
\hline 2 & Desa Maccinibaji & 555,36 \\
\hline \multirow[t]{2}{*}{3} & Desa Balangdatu & 63,87 \\
\hline & Total & $1.106,58$ \\
\hline
\end{tabular}

Sumber: Hasil Analisis, 2019

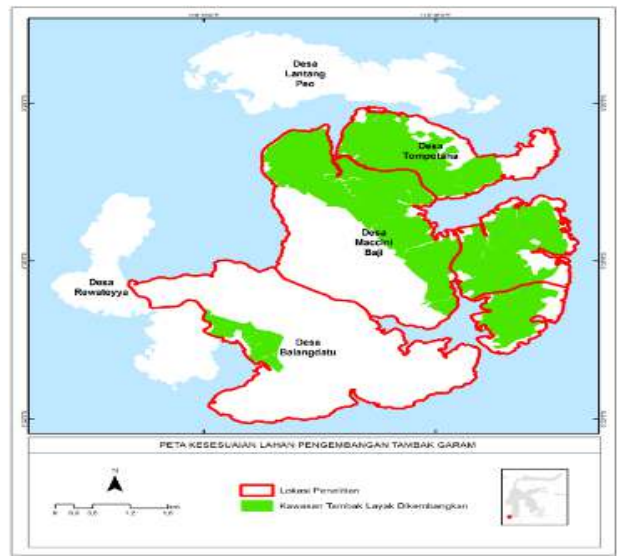

Gambar 12 Peta lahan paling layak dalam pengembangan tambak garam Pulau Tanakeke

\section{Analisis Kelayakan Usaha Tambak}

\section{Garam}

Hasil perhitungan analisis

kelayakan usaha tambak garam dengan metode geomembran pada lahan seluas satu hektar di Pulau Tanakeke layak untuk dijalankan, karena hasil kriteria investasi yang di peroleh bahwa NPV > 1 , Net $\mathrm{B} / \mathrm{C}>1$ dan IRR $>$ discount rate, sehingga memenuhi kriteria yang berlaku.
Tabel 3.Nilai NPV, Net B/C dan IRR usaha tambak garam

\begin{tabular}{clc}
\hline No & Kriteria Investasi & Hasil \\
\hline 1 & NPV (Rp) & $31.962 .284,70$ \\
2 & NET BC-Ratio & 1.10 \\
3 & IRR (\%) & 45 \\
\hline
\end{tabular}

\section{Analisis Strategi Pengembangan}

\section{Tambak Garam}

Berdasarkan hasil Analisis

SWOT yang dilakukan, maka diketahui bahwa terdapat 2 (dua) strategi yang dapat dilakukan dalam pengembangan tambak garam yang ada di pulau Tanakeke yakni:

1) Strategi Prioritas: Pelatihanpelatihan peningkatan kapasitas sumber daya manusia dan Perbaikan infrastruktur.

Prioritas yang akan dilakukan adalah pelatihan-pelatihan yang di kelola secara terpadu dimana pihak investor dan perbankan yang menjadi pendorong pelatihan-pelatihan terpadu ini hal ini dimungkinkan dengan meilihat bahwa ada peluang dengan perhatian yang serius dari pemerintah.

Pelatihan ini juga sebagai sarana untuk meningkatkan akses permodalan dan perbaikan infrastruktur melalui investasi 
$\begin{array}{lll}\text { komersial dimana dilakukan } & \text { dan akan menggairahkan koperasi } \\ \text { perhitungan } & \text { cost-benefit dengan garam. }\end{array}$ melihat tingginya permintaan dan adanya proteksi dan regulasi menyangkut harga garam rakyat dan lahan garam dalam RTRW.Tujuan utama untuk peningkatan teknologi pengelolaan garam misalnya dengan penggunaan geomembrane dan tentunya meniningkatkan kualitas SDM dan kelembagaan petambak garam rakyat.

2) Strategi Alternatif: Perbaikan regulasi tata niaga garam.

Memperbaiki regulasi tata niaga garama sehingga akan mengurangi masuknya garam impor, dan merevitalisasi peran asosiasi garam untuk melawan pasar yang hegemonik dan monopolistik. Hal ini akan mengangkat harga garam dan pada akhinya mengurangi konversi lahan tambak garam untuk tujuan lain.

Dengan mengimplementasikan
prioritas di atas maka akan
mendorong
pemanfaatan potensi garam, dan
melahirkan inovasi pengusahaan
garam yang dilakukan oleh
kelompok-kelompok petani garam

\section{KESIMPULAN}

Berdasarkan uraian maka dirumuskan kesimpulan sebegai berikut:

1. Hasil kesesuaian lahan, teridentifikasi luas total lahan yang paling layak untuk pengembangan tambak garam di Pulau Tanakeke $1.106,58$ ha atau sekitar $46,34 \%$ dari total luas lahan potensial yang tersedia.

2. Nilai kriteria investasi yang diperoleh menunjukan bahwa semua kriteria investasi yang dipersyaratkan dapat terpenuhi, sehingga pengusahaan tambak garam di lokasi penelitian layak untuk dikembangkan.

3. Strategi yang dapat dilakukan dalam pengembangan tambak garam di lokasi penelitian yakni;Strategi Prioritas; Pelatihanpelatihan peningkatan kapasitas sumber daya manusia dan Perbaikan infrastruktur,danStrategi Alternatif; Perbaikan regulasi tata niaga garam. 


\section{SARAN}

1. Dalam upaya pengembangan tambak garam di lokasi penelitian, sebaiknya pemerintah daerah setempat lebih memfokuskan perhatian pada pendampingan masyarakat yang lebih intens seperti memaksimalkan peran penyuluh perikanan dalam memberikan pendampingan kepada petambak garam.

2. Perlu dilakukan kajian lanjutan terkait dengan permasalahan aksesibilitas pemasaran hasil produksi yang terjadi pada musim tertentu (gelombang air laut yang tinggi) dimana pada saat musim ini masyarakat kesulitan untuk mendistribusikan hasil produksinya ke pasar.

\section{UCAPAN TERIMA KASIH}

Hasil kajian ini merupakan bagiandari penelitian Tesis dan penulis mengucapkan terima kasih kepada KetuaProdi Manajemen Pesisir dan TeknologiKelautan dan Direktur Pasca Sarjanayang telah memberi kesempatan untukmelanjutkan pendidikan di PPS UMI.

\section{DAFTAR PUSTAKA}

Antara News. 2017. DKP Sulsel Fokus Pengembangan Usaha Garam Rakyat.

(Internet)..http://www.antarane ws.com (diakses 05 Juli 2017).

[BPS] Badan Pusat Statistik. 2019. Kabupaten Takalar Dalam Angka 2019. BPS Kabupaten Takalar.

Dinas Kelautan dan Perikanan Provinsi Sulawesi Selatan.2017.Laporan Statistik Dinas Kelautan dan Perikanan Provinsi Sulawesi Selatan.

Dinas Kelautan dan Perikanan Provinsi Sulawesi Selatan.2018.Laporan Statistik Dinas Kelautan dan Perikanan Provinsi Sulawesi Selatan.

Kadariah, L., Karlina dan C. Gray. 1978. Pengantar Evaluasi Proyek. Lembaga Penerbit FEUI.

Kadarsan, H. W. 1995. Keuangan Pertanian dan Pembiayaan Perusahaan

Agribisnis.Gramedia Pustaka Utama Jakarta.

Muhsoni F. Farid. 2012. Kesesuaian Lahan Tambak Garam Menggunakan Sistem Informasi Geografis di Kabupaten Sampang. Skiripsi. Program Studi Ilmu Kelautan Fakultas Pertanian Universitas Trunojoyo Madura.

Rahman et all. 2017. Analisis Pola Pasang Surut Di Sepanjang Perairan Takalar- Makassar. [Artikel].Universitas Hasanuddin.

Rochwulaningsih Y. Tata Niaga Garam Rakyat Dalam Kajian Struktural. Jurnal Sejarah CITRA LEKHA, Vol. XVII, No. 1 Februari 2013: 59-66 